magazines; a Science Section was formed under the chairmanship of Sir Richard Gregory and a Press Committee of British and Russian journalists met. Later, various other sections were formed and the Society steadily increased in membership. Each year has seen new developments, and since the War both the status and the influence of the Society have been heightened; it has been recognized that only by keeping exclusively to the one purpose of fostering cultural relations can the Society hope to make a wide appeal. It now has a good library and a panel of lecturers, and it is prepared to deal with inquiries coming within its ambit. We wish the Society continued success in the important and difficult tasks that will confront it in the post-war years.

\section{Indian Famine Inquiry}

THE Government of India has announced the following names of the chairmen and members of the famine inquiry commission: Sir John Woodhead, Finance Member of the Government of Bengal 19321937, Governor of Bengal during June-November, 1939 (chairman); Mr. S. V. Ramamurti, adviser to the Governor of Madras and formerly director of agriculture, Madras; Dr. W. R. Aykroyd, director of the Nutritional Research Laboratory, Coonoor; Khan Bahadur Mien Afzal Hussain, formerly principal of the Agricultural College, Lyallpur ; Sir Manilal B. Nanavati, president of the Indian Society of Agricultural Economics, deputy governor of the Reserve Bank of India during 1936-1941, and an authority on sociological and agricultural problems; Mr. R. A. Gopalaswami (secretury), assisted by Rai Bahadur D. N. Maitra.

\section{Higher School Certificate Biology}

THE content and form of the traditional syllabus for the Higher School Certificate examination are frequently influenced by the older point of view that biology, botany and zoology are intellectual disciplines unrelated to ordinary life, and, further, that anything relating to human beings lies in the province of anatomy and physiology in the medical curriculum. Modern opinion is that such studies are closely interwoven with our own lives and that, while they may serve as an introduction to subsequent professional or university courses, they should also form, because of their method and content, an essential part of the education of the ordinary eitizen. Some progress has been made in this direction by slight emendations or re-interpretations of existing syllabuses; but a Joint Advisory Committee for Biology was set up by the University of Cambridge in June 1943 to recast thoroughly the syllabuses for the Cambridge Local and Oxford and Cambridge Schools examinations. The Committee included representatives of the teaching profession and of the University of Cambridge, and also had the advice of one of H.M. inspectors of secondary schools, members of the University of Oxford, the Matriculation and School Examinations Council of the University of London, and the Central Welsh Board.

The resulting syllabuses, quite new in content and outlook, are not regarded as definitive, but criticisms are invited and it is proposed to issue a revised edition if, when they have been given a trial, it is found that modifications are necessary. The syllabus of each subject is fully set out and, in zoology, detailed notes explaining the intention of the various parts of the syllabus are provided. The content is arranged for a course extending over two school years and assumes that 450 periods each of forty minutes are available. A useful feature of the report is that each subdivision of a subject is followed by a suggestion of the approximate number of periods that should be devoted to it. These suggestions, if followed in a reasonable and not slavish manner, should result in a well-balanced course without overweighting particular parts and at the same time allow latitude for individual circumstances. In the opinion of the writer of this note the syllabuses are a welcome improvement on most of those at present in effect and decidedly a move in the right direction, particularly if more attention is given to the individual practical work of the pupils : but-the proof of the pudding is in the eating. Copies of the report can be obtained from the Cambridge University Press, 200, Euston Road, London, N.W.1, price 6d. (7d. including postage).

\section{Apprenticeship and the New Education Bill}

Some strong eriticisms of the raising of the schoolleaving age envisaged under the new Education Bill are given in a recent pamphlet on "Apprenticeship for a Skilled Trade" by Mr. F. Twyman, managing director of the well-known optical firm of Messrs. Adam Hilger, Ltd. (London : Charles Griffin and Co., Ltd. 5s. net). Thus he says, "Besides tending towards the disappearance of skilled craftsmen and arresting the development of individual boys, the proposed deferment of the school-leaving age will lessen the productive capacily of the nation just at a time when it should be increased". Mr. Twyman speaks in no uncertain terms against the views of those who seem to regard it as self-evident that, schooling being a good thing, the longer it is continued the better; and he claims that there is a general neglect of the fact that at the age of fourteen many normal boys become impatient of learning unless they see some useful result. $\mathrm{He}$ believes that the skilled trades can best be satisfactorily recruited through a scheme of apprenticeship commencing at fourteen years of age under which boys would enter the trade with part. time day release to attend school, varying from two days a week at fourteen to one day at eighteen years of age. The scheme would be based upon the following four main premises : (1) industry needs more good craftsmer ; (2) these can only be attained by apprenticeship; (3) the apprenticeship contract must embody a curriculum; (4) independent inspection must be provided to ensure that the terms of the contract are fulfilled.

There is good sense in much of what Mr. Twyman says about the need for realis $m$ in modern education, and he would probably be surprised to find that a large number of educationists agree with him; indeed, his proposed scheme of apprenticeship is essentially educational in character, since the young apprentice, instead of wasting his early years in making tea and running errands, would from the start learn practical subjects in the works under strict supervision. Mr. Twyman's essay certiainly suggests a valuable seheme for co-operation between school and industry, which should fittingly be examined at the present time.

\section{Bureau of American Ethnology}

IN spite of its increasing concern with the war effort, the Bureau of Ameriean Ethnology still manages to carry out some of its normal activities (Sixtieth Annual Report: June 1942 to June 1943. 
Pp. 10. Washington: Gov. Printing Ofice). Although the general policy is not to undertake field work during the War, special eircumstances made it advisable to make a preliminary investigation of a site in the Agate Basin, East Wyoming. This yielded points of general Yuma character, but of relatively recent date. Dr. Stirling, chief of the Bureau, took charge of a further National Geographic Society Smithsonian Institution Expedition to southern Mexico, which continued excavations at La Venta. Publication continued, and it is good to hear that the great "Handbook of South American Indians" is three-quarters complete. Three bulletins were issued, and eight were in the press at the end of the year. Members of the staff were active in promoting interAmerican co-operation, and with this end in view the Inter-American Society of Anthropology and Geography was formed. A quarterly journal, Acta Americana, is ' to be issued. Specifically war-like activities comprised the preparation of various Smithsonian Institution War Background Studies and publications of the Ethnogeographic Board, besides the answering of numerous questions from the armed forces.

\section{Ophthalmological Research at Leeds}

ON the recommendation of a special committee, the Council of the University of Leeds has adopted a scheme for the establishment of an Ophthalmological Research Centre. As soon as the necessary funds are available, the Council will proceed to the appointment of research fellows to work on special problems concerned with the prevention and cure of blindness and other diseases of the eye. X-ray equipment, the recently installed electron microscope and other facilities will be made available for the work in the University. The maintenance and development of the Centre will te in the hands of an Ophthalmological Research Advisory Committee.

\section{Cfficers and Trustees of Science Service}

THE following have been re-elected officers of Science Service, the American institution for the popularization and interpretation of science : president, Dr. E. G. Conklin ; vice-president and chairman of the Executive Committee, Dr. Harlow Shapley; treasurer, 0. W. Riegel; secretary, Watson Davis. Dr. Otis W. Caldwell, of the Boyce Thompson Institute for Plant Research and general secretary of the American Association for the Advancement of Science, and Max B. Cook, promotion editor of Soripps-Howard newspapers, have keen elected to the Board of Trustees, which is now constituted as follows, the bodies represented by the trustee being indicated in brackets: Dr. Otis W. Caldwell, Dr. Edwin G. Conklin, president of the American Philosophical Society, and Dr. Henry B. Ward, University of Illinois (American Association for the Advancement of Science); Dr. Warren H. Lewis, Wistar Institute of Anatomy and Biology, Dr. R. A. Millikan, California Institute of Technology, and Dr. Herlow Shapley, director of the Harvard College Observatory (National Academy of Sciences); Dr. C. G. Abbot, secretary of the Smithsonian Institution, Dr. Ross G. Harrison, chairman of the National Research Council, and Prof. Hugh S. Taylor, Princeton University (National Research Council); A. H. Kirchhofer, managing editor of the Buffulo Evening News, O. W. Riegel, Washington and Lee School of Journalism, now on war leave with the Office of War Information, and Neil H. Swanson, executive editor of Sun papers (journalistic profession); Max B. Cook, Frank R. Ford, editor, Evansville Press, and H. L. Smithton, executive agent of the E. W. Scripps Trust (E. W. Scripps Estate).

\section{Night Sky in August}

Fuld moon occurs on August 4d. 12h. 39m. ए.T., and new moon on August 18d. 20h. 25m. The following conjunctions with the moon take place: Aug. 14d. 20h., Saturn $1^{\circ}$ N. ; Aug. 20d. 03h., Venus $2^{\circ}$ S.; Aug. 20d. 19h., Mercury $8^{\circ}$ S.; Aug. 2ld. 04h., Mars $4^{\circ} \mathrm{S}$. In addition to the above, the following conjunctions also take place: Aug. 13d. 13h., Venus in eonjunction with Jupiter, Venus $0 \cdot 6^{\circ} \mathrm{N}$.; Aug. $26 \mathrm{~d}$. 15h., Mercury in conjunction with Venus, Mercury $6 \cdot 1^{\circ} \mathrm{S}$. Mercury reaches its greatest eastern elongation on Aug-10. The planet sets at $20 \mathrm{~h} .38 \mathrm{~m} ., 19 \mathrm{~h}$. $51 \mathrm{~m}$. and $18 \mathrm{~h} .38 \mathrm{~m}$. at the beginning, middle and end of the month respectively. Venus is too close to the sun to be favourably observed, setting about half an hour after sunset during the month. Mars, Jupiter and Saturn are not well placed for observation, though Saturn is becoming visible in the early morning hours, rising about midnight towards the middle of the month. The Perseid meteors reach their maximum on Aug. 10-12.

\section{Announcements}

Ат a meeting of the Council of the Institute of Fuel, held this month, it was announced that Dr. E. W. Smith has agreed to continue in office as president for a further period of twelve months, that is, until October 1945. It was also announced that the Melchett Medal for 1944 has been awarded to Dr. J. G. King, director of the Gas Research Board, in recognition of the outstanding work he has done in recent years during his long connexion with the Fuel Research Station at Greenwich; and that Mr. H. L. Pirie, one of the honorary secretaries of the Institute of Fuel since its inception, has keen made an honorary member.

THE following have been elected officers of the Institution of Electrical Engineers for the session 1944-45: President, Sir Harry Railing; Vice-President, W.. J. H. Wood; Honorary Treasurer, E. S. Byng; New Members of Council, H. Bishop, W. N. C. Clinch, F. C. Winfield, and Dr. R. W. Sillars.

ThE Chadwick Trustees are offering an award of $£ 250$ for an investigation of the reasonable maximum 'density' range (per acre) for small houses with gardens, suitable especially for the intermediate and outer zones of large towns-with due regard to the amenities essential to a comprehensive town planning arrangement. Applications, in writing, must reach the Clerk to the Chadwick Trustees, 204 Abbey House, Westminster, London, S.W.1, before the end of September, accompanied by evidence of qualifications and a brief statement of the general plan of research proposed.

REFERRING to the review in Nature of March 18, p. 327 , of "Frontiers in Cytochemistry", the editor, Prof. Normand L. Hoerr, has pointed out that he was incorrectly described as the successor of Prof. R. R. Bensley in the chair of anatomy in the University of Chicago ; Prof. Hoerr is professor of anatomy at Western Reserve University, Cleveland, Ohio. 